\title{
Centering AbILITY, CANAL tRAnsportation AND SURFACE MOdifications of ProTaper F2 AND F3 USED In CONTINUOUS ROTATION AND RECIPROCATING MOTION IN CURVED ROOT CANALS
}

\author{
Habilidade de centralização, transporte do canal e modificações \\ de superfície do ProTaper F2 e F3 utilizados em rotação contínua \\ e movimento reciprocante em canais curvos
}

\author{
Jader Vinicius Andreazza ${ }^{a}$ \\ Miguel Assis Martins dos Santos ${ }^{b}$ \\ Lucas Siqueira Pinheiro ${ }^{c}$ \\ Júlia Eick Iglesias ${ }^{\mathrm{d}}$ \\ Fernanda Ullmann Lopez \\ Fabiana Soares Crecca $^{f}$
}

\begin{abstract}
Aims: To evaluate the centering ability, canal transportation and surface modifications of F2 and F3 ProTaper Universal (PT) instruments used in continuous rotation (CR) and reciprocating motion (RM) for the preparation of curved root canals. Material and methods: sixty mesiobuccal root canals of upper molars with curvatures between $25^{\circ}$ and $35^{\circ}$ were divided into three groups: I - PT in CR up to F3; II - PT in RM up to F3; III - F2 and F3 PT instruments in RM. Cone Beam Computed Tomography images were obtained before and after instrumentation. The scans were superimposed to determine the centering ability and canal transportation in apical, medium and cervical thirds. The apical $6 \mathrm{~mm}$ of the F2 and F3 files were evaluated under Scanning Electron Microscope before and after 1, 3 and 6 uses to assess distortion, surface wear and
\end{abstract}

fracture. The statistical analysis of centering ability and canal transportation were performed by Kruskal-Wallis and ANOVA, respectively. The scores for deformation and surface wear were compared using ANOVA. Fisher's exact test was used for the evaluation of instrument fracture. Results: there were no significant differences between groups regarding centering ability and canal transportation, as well as, for distortion, surface wear and fracture ( $p>$.05). Conclusion: F2 and F3 instruments can be used for curved canals instrumentation. However, when used for entire canal preparation, F2 and F3 should be discarded after single use.

Keywords: Endodontics. Root canal preparation. Cone beam computed tomography.

\footnotetext{
${ }^{a}$ Cirurgião-dentista, Unicsul - Unidade Avançada de Pós-Graduação de Caxias do Sul, Caxias do Sul, RS, Brasil.

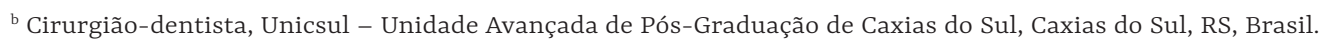

' Cirurgião-dentista, Mestre em Endodontia, Faculdade de Odontologia, Universidade Federal do Rio Grande do Sul, Porto Alegre, RS, Brasil. ${ }^{d}$ Cirurgião-dentista, Mestre em Endodontia, Faculdade de Odontologia, Universidade Federal do Rio Grande do Sul, Porto Alegre, RS, Brasil.

${ }^{\text {e }}$ Cirurgiã-dentista, Mestre e Doutora em Endodontia, Unicsul - Unidade Avançada de Pós-Graduação de Caxias do Sul, Caxias do Sul, RS, Brasil. ${ }^{\mathrm{f}}$ Cirurgiã-dentista, Mestre e Doutora em Endodontia, Faculdade de Odontologia, Universidade Federal do Rio Grande do Sul, Porto Alegre, RS, Brasil. Autor de correspondência: Fabiana Soares Grecca - E-mail: fabiana.grecca@ufrgs.br
} 


\section{RESUMO}

Objetivos: avaliar a centralização, transporte do canal e modificações de superfície dos intrumentos ProTaper Universal (PT) F2 e F3 utilizados em movimento de rotação continua (CR) e movimento reciprocante (RM) no preparo de canais curvos. Materiais e métodos: sessenta canais mesiovestibulares de molares superiores com curvaturas entre 250 e 350 foram divididos em três grupos: I - PT em CR até F3; II - PT em RM até F3; III - instrumentos F2 e F3 em RM. Foram obtidas imagens de Tomografia Computadorizada Cone Beam antes e após a instrumentação. As imagens foram sobrepostas para determinar a centralização e transporte do canal nos terços apical, médio e cervical. Os 6 mm apicais dos instrumentos F2 e F3 foram avaliados por Microscopia Eletrônica de Varredura antes e após 1, 3 e 6 usos para verificar distorções, desgaste de superfície e fratura. A análise estatística da centralização e transporte do canal foi feita pelos testes de Kruskall-Wallis e ANOVA, respectivamente. Os escores de deformação e desgaste de superfície foram comparados pelo teste de ANOVA. O teste exato de Fisher foi utilizado para avaliar a fratura dos instrumentos. Resultados: não houve diferença estatística entre os grupos testados quanto aos testes de centralização e transporte do canal, assim como para distorção, desgaste de superfície e fratura dos instrumentos ( $\mathrm{p}>$.05). Conclusões: os instrumentos F2 e F3 podem ser utilizados no prepare de canais curvos. Entretanto, quando usados para o preparo completo do canal radicular, F2 e F3 devem ser descartados após uso único.

Palavras-chave: Endodontia. Preparo do canal radicular. Tomografia computadorizada de feixe cônico.

\section{INTRODUCTION}

A successful outcome in endodontics is directly dependent on the cleaning and shaping of the root canal system ${ }^{1}$. There is a continuous search to improve instruments performance and techniques, in terms of root canal wall cleanness and maintenance of its original shape.

The increased flexibility of nickel-titanium (Ni-Ti) instruments have significantly improved the quality of root canal shaping ${ }^{2}$ with less canal transportation, dentin preservation and reduced risk of zipping or stripping curved canals ${ }^{3}$. Despite these advantages, when used in continuous rotation (CR), instrument fracture by torsional failure or cyclic fatigue can occur $^{4}$, and these problems can be attributed to the continuous rotation ${ }^{5}$. Also, tooth structure and organic debris were observed on the surface of NiTi rotary instruments even after ultrasonic cleaning and decontamination ${ }^{6}$ Therefore, the single use of these instruments is desirable in order to reduce fracture and avoid cross-contamination.

A concept introducing NiTi systems in reciprocating motion (RM) was proposed with the aim to reduce the number of instruments, cost, instrument fatigue and cross-contamination ${ }^{7}$. The reciprocating working motion consists of a counterclockwise (cutting direction) and a clockwise motion (release of the instrument), while the angle of the counterclockwise cutting direction is greater than the angle of the reverse direction. Due to the fact that the counterclockwise angle is greater than the clockwise one, it is believed that the instrument continuously progresses towards the terminus of the root canal. ${ }^{8}$ The use of this motion has been recommended to improve the fracture resistance of endodontic instruments during root canal preparation ${ }^{7,9,10}$. The incidences of instrument separation and deformations of reciprocating file systems were reported to be considerably low ${ }^{2,9,11}$. Besides investigating the instrument modifications after the canal preparation, it is important to evaluate its shaping ability in this new kinematics.

The aim of the present study was to investigate the centering ability, canal transportation and surface modifications of F2 and F3 ProTaper Universal (PT) instruments used in CR and RM for the preparation of curved root canals. 


\section{Material AND METHOdS}

The present study was approved by the Ethics in Research Committee from the Federal University of Rio Grande do Sul (Protocol \# 22579). Sixty extracted upper molars were radiographed in the buccal-palatal direction to confirm complete root canal formation and the absence of calcifications, resorptions and previous root canal manipulation. The teeth were sectioned through the furcation and the mesial root was separated from the others. Mesial canals with curvatures between $25^{\circ}$ and $35^{\circ}$, according to Schneider's technique $(1971)^{12}$, and with a diameter of at least a \#10 file were included.

The working length was determined visually by subtracting $1 \mathrm{~mm}$ from the apical foramen. After, the apex of each canal was sealed with sticky wax and roots were fixed in an acrylic block, emerging only the first $2 \mathrm{~mm}$ of the cervical third. The blocks were fixed to an acrylic board for the pre- and post-operative images acquisition. Roots were randomly divided into 3 groups $(\mathrm{n}=20)$ :

Group I: twenty canals were prepared with the PT full-sequence (Dentsply Maillefer, Ballaigues, Suíça) in CR up to F3. The sequence of instruments that were used in a slow pecking motion was S1, SX, S1 and S2 up to two-thirds of the canal length, or until resistance. Preparation was completed with F1, F2 and F3 up to the working length in a push-pull filing motion.

Group II: twenty canals were prepared with the PT full-sequence in RM up to F3. The same sequence of instruments from Group I was used in a slow pecking motion.

Group III: twenty canals were exclusively prepared with the F2 and F3 instruments in RM. The F2 instrument was introduced up to the working length followed by F3 using the same kinematics described for Group II.

A single experienced and trained endodontist carried out canals instrumentation. X-Smart Plus (Dentsply Maillefer, Ballaigues, Switzerland) was used to prepare the canals in CR and RM. In all groups, after each instrument change, canals were irrigated with $2 \mathrm{~mL}$ of $2.5 \%$ sodium hypochlorite and recapitulation was carried out with a \#10 File up to the working length. Final irrigation was performed with $2 \mathrm{~mL}$ of $17 \%$ Ethylenediamine tetraacetic acid (EDTA), which was manually agitated for 3 minutes, followed by a final flush of $2 \mathrm{~mL}$ of $2.5 \%$ sodium hypochlorite. Canals were then dried with sterilized paper points.

Each instrument was used to prepare six canals in the groups I and II. In case of any fracture or permanent deformation, it was registered and this instrument was replaced for a new one. In the group III, a new instrument was used for each canal preparation.

\section{Images assessment}

The samples were scanned by the i-CAT CBCT unit (Imaging Sciences, Hatfield, United States) set at $120 \mathrm{KVp}, 5 \mathrm{~mA}$ with a $16-\mathrm{cm}$ field of view at $0.2-\mathrm{mm}$ voxel. The exposure time was $26.9 \mathrm{~s}$. The scanning was performed in slices of $1 \mathrm{~mm}$ thickness.

Cone Beam Computer Tomography (CBCT) images were obtained from the roots before and after instrumentation. After preparation, roots were replaced in the acrylic device, in the same exact position, in order to perform a new scan using the same parameters. 


\section{Images analysis}

A single experienced and previously calibrated evaluator held two separate viewing sessions for all tomographic exams separated by a two-week interval. The Dicom files were exported to OsiriX 5.8.5 software (OsiriX Imaging Software, Pixmeo, Geneva, Switzerland) and the evaluation of pre- and post-instrumented root canals was carried out at the following levels:

a) cervical third: 3 slices above the one where the canal opening was completely visualized

b) middle third: half point section between the apical and cervical sections

c) apical third: 3 slices under the apical foramen

Image zoom was standardized in $601 \%$ and the color look-up table (CLUT) editor was modified for the GEcolor option (Figure 1).

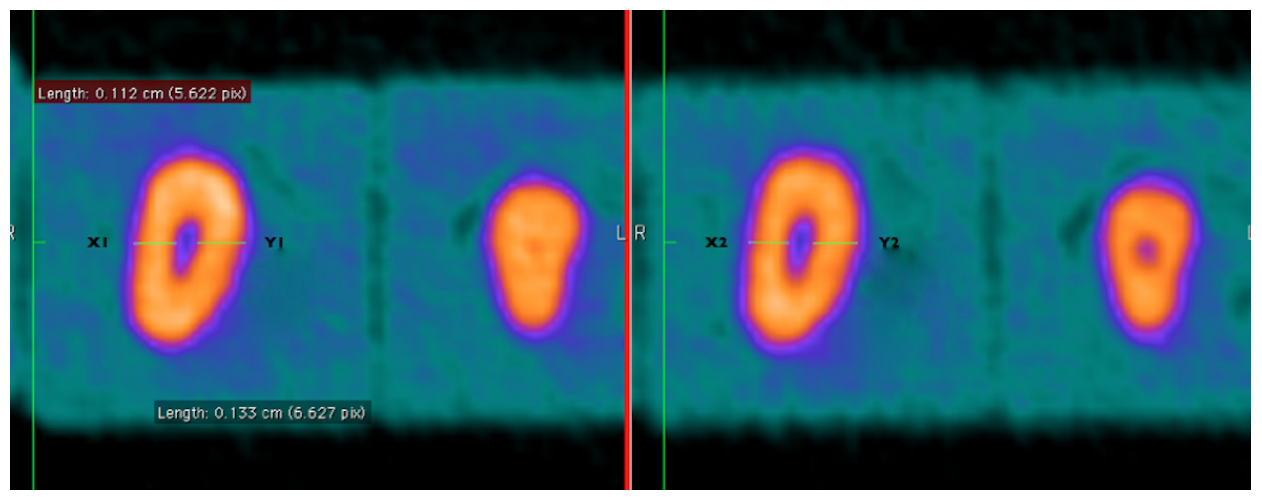

Figure 1: CBCT images of the pre- and postoperative images.

$X_{1}=$ shortest distance from the internal aspect of the root to the periphery of the uninstrumented canal.

$\mathrm{X}_{2}=$ shortest distance from the internal aspect of the root to the periphery of the prepared canal.

$Y_{1}=$ shortest distance from the external aspect of the root to the periphery of the uninstrumented canal.

$Y_{2}=$ shortest distance from the external aspect of the root to the periphery of the prepared canal.

The pre- and post- instrumentation scans were superimposed and canal transportation and centering ability were measured according to Gambill, Alder and del Rio (1996) ${ }^{13}$. The following formula was used for the calculation of transportation:

$$
\left(X_{1}-X_{2}\right)-\left(Y_{1}-Y_{2}\right)
$$

$\mathrm{X}_{1}$ represents the shortest distance from the furcal (distal) aspect of the root to the periphery of the uninstrumented canal. $\mathrm{X}_{2}$ represents the shortest distance from the furcal (distal) aspect of the root to the periphery of the prepared canal. Y1 represents the shortest distance from the mesial aspect of the root to the periphery of the uninstrumented canal. $Y_{2}$ represents the shortest distance from the mesial aspect of the root to the periphery of the prepared canal. A result of zero indicated no canal transportation; a positive result indicated transportation towards the furcal (distal) aspect of the root; a negative result indicated transportation towards the mesial aspect of the root.

For the evaluation of centring ability, the ratio was calculated for each section using the following formula:

$$
\left(X_{1}-X_{2}\right) /\left(Y_{1}-Y_{2}\right) \text { or }\left(Y_{1}-Y_{2}\right) /\left(X_{1}-X_{2}\right)
$$


The numerator for this formula was the smaller of the two numbers $\left(\mathrm{X}_{1}-\mathrm{X}_{2}\right)$ or $\left(\mathrm{Y}_{1}-\mathrm{Y}_{2}\right)$, if these numbers were unequal. A result of one would indicate perfect centering ability; the closer the result is to zero, the worse the ability is of the instrument to remain centred.

\section{Evaluation of F2 and $F_{3}$ surface modifications and fracture}

The final $6 \mathrm{~mm}$ of F2 and F3 instruments were evaluated under Scanning Electron Microscope (SEM) (JEOL 6060, Tokyo, Japan), before and after 1, 3 and 6 uses under 55x and 250x magnification. Previously, each instrument was washed under ultrasonic vibration during 5 minutes. These instruments were mounted on a stub in a standardized position.

Two previously calibrated evaluators held the analysis of the instruments. Scores were given to each instrument according to Troian et al. (2006) ${ }^{14}$ using three different criteria: distortion of instrument spirals, instrument surface wear and instrument fracture.

\section{Statistical analysis}

Two blinded examiners performed the analysis of the images in agreement, with an intraclass correlation coefficient (ICC) of 0.93 for canal transportation and centering ability measurements; 0.8 for spiral distortion and surface wear; and 1.00 for instrument fracture. Canal transportation and centering ability of each instrumentation technique in the apical, middle and coronal thirds were compared statistically using Kruskal-Wallis and One-way Analysis of Variance (ANOVA), respectively. Significance level was preset at .05. The deformation and wear scores were compared using repeated measures ANOVA. The Fisher's exact test was used for the evaluation of the categorical variables of instrument fracture. Data were analyzed using the SPSS 11.0 software (IBM SPSS Statistics 20; SPSS, Chicago, IL, USA).

\section{RESULTS}

\section{Canal transportation}

There was no statistical difference among the techniques tested in the 3 thirds of root canals (p>.05) (Table 1). In the cervical third, instrumented canals were transported towards the distal surface of the root. In the apical and middle thirds canals were transported towards the mesial surface.

Table 1: Mean transportation $(\mathrm{mm})$ of the canals after preparation.

\begin{tabular}{lccc}
\hline Group & $\begin{array}{c}\text { Apical-Third } \\
(\text { mean } \pm \text { SD) }\end{array}$ & $\begin{array}{c}\text { Middle-Third } \\
(\text { mean } \pm \text { SD })\end{array}$ & $\begin{array}{c}\text { Coronal-Third } \\
(\text { mean } \pm \text { SD })\end{array}$ \\
\hline PT Continuous Rotation & $-.0489 \pm .12438$ & $-.0365 \pm .18447$ & $.1658 \pm .18925$ \\
PT Reciprocating Motion & $-.0387 \pm .07270$ & $-.0547 \pm .15013$ & $.1848 \pm .18369$ \\
F2/F3 Reciprocating Motion & $-.0249 \pm .10220$ & $-.0044 \pm .13131$ & $.1269 \pm .17817$ \\
\hline P & .552 & .818 & .645 \\
\hline
\end{tabular}




\section{Centering ability}

All techniques presented good centering ability in the thirds evaluated with no statistically significant differences between them ( $p>.05$ ) (Table 2).

Table 2: Centering ratio $(\mathrm{mm})$ of the canals after preparation.

\begin{tabular}{lccc}
\hline Group & $\begin{array}{c}\text { Apical-Third } \\
(\text { mean } \pm \text { SD })\end{array}$ & $\begin{array}{c}\text { Middle-Third } \\
(\text { mean } \pm \text { SD })\end{array}$ & $\begin{array}{c}\text { Coronal-Third } \\
(\text { mean } \pm \text { SD })\end{array}$ \\
\hline PT Continuous Rotation & $.5242 \pm .32866$ & $.4977 \pm .31737$ & $.4723 \pm .26146$ \\
PT Reciprocating Motion & $.5106 \pm .31915$ & $.4152 \pm .31644$ & $.3566 \pm .29289$ \\
F2/F3 Reciprocating Motion & $.5007 \pm .34436$ & $.4255 \pm .26558$ & $.4494 \pm .29725$ \\
\hline P & .975 & .587 & .401 \\
\hline
\end{tabular}

\section{Deformation and fracture}

One F2 separated in Group II during the sixth use. For all preparation techniques, there were no significant statistical differences for distortion, wear surface and fracture (p>.05) (Figure 2).
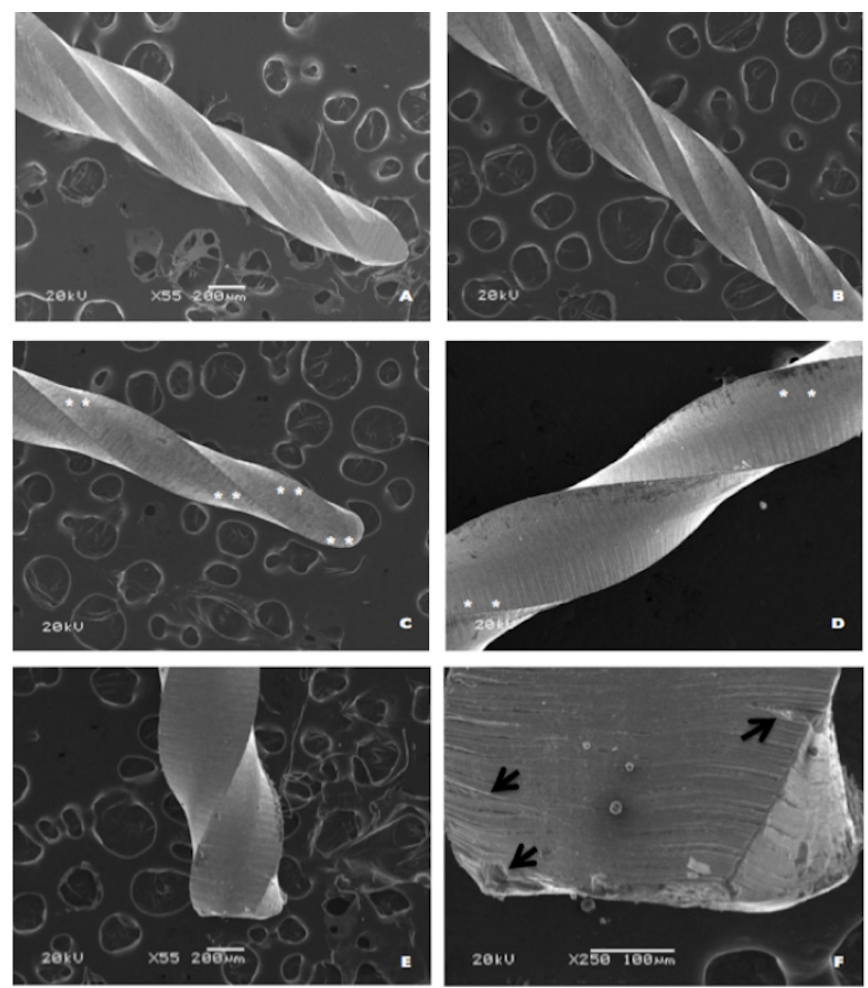

Figure 2: ProTaper instruments: with no distortions and surface wear (SEM images, $200 \mu \mathrm{m}, 55 \times$ magnification).

A- F2 no use. B- F2 after sixth use. C-F3 no use. D- F3 after sixth use; with surface wear (**).

C-F2 after sixth use. D- F2 after first use; E- F2 (group II) fractured during the sixth use.

F-Arrows evidencing microcracks (SEM images, $200 \mu \mathrm{m}, 250 \times$ magnification). 


\section{DISCUSSION}

In the last few years, studies have shown the importance of a larger apical diameter in teeth with necrotic pulps associated with periapical lesions, especially due to the difficulty to remove biofilm from this region, which can lead to treatment failure ${ }^{15,16,17}$. In this cases, an adequate apical preparation increases the success rates by means of improving cleanliness and disinfectio ${ }^{18}$. However, excessive apical enlargement may cause an unnecessary dentin removal, which is a concern especially in curved canals ${ }^{19}$. Canal transportation is another aspect of concern during instrumentation of curved canals, especially in the apical third. The maintenance of necrotic remnants and microorganisms that were not removed from the root canal could lead the therapy to failure ${ }^{20,21}$.

In the present study, all groups tested produced centered preparations with no substantial canal transportation. Results also showed that different kinematics as well as the number of instruments used did not significantly influenced the mean transportation and centering ability of the three protocols tested. Other studies have also shown the ability of rotary $\mathrm{Ni}-\mathrm{Ti}$ instruments to stay centered in the canal, keeping the risk of canal transportation at levels without clinical relevance ${ }^{22,23,24,25}$.

In all groups, little transportation occurred towards the furcation in the cervical third and towards the external wall in the middle and apical thirds. These results are in accordance with the findings of other studies ${ }^{23,24,26}$. Avoiding canal transportation in these directions is easily explained based on the understanding of molars internal anatomy. The presence of double curvature requires a coronal preflaring, which provides instrument free access up to the apical third. This step would enhance the maintenance of centralized canals ${ }^{27}$.

The concept of a single-file technique using PT F2 was introduced by Yared (2008). After that, other studies have evaluated the same protocol showing favorable results with respect to centering ability of the reciprocant cinematic ${ }^{28,29,30}$. In the present study, F3 instrument was used in Group III, providing greater apical final enlargement when compared to the other studies ${ }^{11,26,31}$. However, the increase of the apical final file did not result in significant canal transportation. Even though no instrument or technique is able to touch all canal walls during instrumentation, a greater apical enlargement could have the advantage of improving pulp tissue removal, bacteria and their by-products, while providing adequate canal shape for filling ${ }^{17,21,32}$.

Lately, new systems that employ single-file technique were introduced. However, the use of these instruments especially designed for RM is not mandatory, as the present study has demonstrated the possibility to perform root canal preparation using only F2 and F3 files. Kim et al. (2013) compared the shaping ability of the single-file PT F2 and WaveOne Primary in curved root canals and verified that there were no difference in root canal volume, surface area and structure model index between them ${ }^{33}$. Agreeing with the present results, their study showed a similar transportation toward the external aspect of the curvature at 1 and $2 \mathrm{~mm}$ levels, and toward the furcation at 3 and $5 \mathrm{~mm}$ levels ${ }^{33}$.

Regarding instrument distortions, surface wear and fracture, no statistical differences were found between PT F2 and F3 instruments after 1, 3 and 6 uses, regardless the protocol used. Nevertheless, for some instruments, the number of uses increased spiral distortion and surface wear, agreeing with other studies that investigated the occurrence of defects on NiTi rotary instruments after use $\mathrm{e}^{10,34,35,36,37,38}$.

Varela-Patiño et al. (2010) evaluated deformations and surface wear of PT instruments after use in $\mathrm{CR}$ and $\mathrm{RM}^{10}$. The authors found that instruments could be used four to five times in CR while they could be used up to ten times in RM, suggesting that RM increased the resistance of the instruments to fracture. You et al. (2010) also compared PT full-sequence 
in $\mathrm{CR}$ and F2 in $\mathrm{RM}^{11}$. They found that F2 could be safely used up to six times for preparation of curved canal in RM.

In the present study, five instruments presented signs of surface wear in the first SEM evaluation (pre-operative analysis), characterizing manufacturing defects. However, file separation occurred for only one of them (F2, group II).

\section{CONCLUSIONS}

There were no clinical differences in the curved canals shaped by the protocol using F2 and F3 instruments in RM when compared to PT full-sequence used in CR and RM regarding centering ability and canal transportation. Although, when used for entire canal preparation, F2 and F3 should be discarded after single use.

\section{REFERENCES}

1. Schilder H. Cleaning and shaping the root canal. Dent Clin North Am. 1974;18(2):269-96.

2. Lim Y, Park ], Kim C. Comparison of the centering ability of Wave. One and. 2013;7658:21-5.

3. Esposito PT, Cunningham C]. A comparison of canal preparation with nickel-titanium and stainless steel instruments. J Endod. 1995;21(4):173-6.

4. Parashos P, Messer HH. Rotary NiTi Instrument Fracture and its Consequences. ] Endod. 2006;32(11):1031-43.

5. Walia H, Brantley WA, Gerstein H. An initial investigation of the bending and torsional properties of nitinol root canal files. J Endod. 1988;14(7):346-51.

6. Sonntag D, Peters OA. Effect of Prion Decontamination Protocols on Nickel-Titanium Rotary Surfaces. ] Endod. 2007:33(4):442-6.

7. Yared G. Canal preparation using only one Ni-Ti rotary instrument: Preliminary observations. Int Endod ]. 2008;41(4):339-44.

8. Bürklein S, Benten S, Schäfer E. Shaping ability of different single-file systems in severely curved root canals of extracted teeth. Int Endod ]. 2013;46(6):590-7

9. De-Deus C, Moreira EJL, Lopes HP, Elias CN. Extended cyclic fatigue life of F2 ProTaper instruments used in reciprocating movement. Int Endod ]. 2010;43(12):1063-8.

10. Varela-Patiño P, Ibañez-Párraga A, Rivas-Mundiña B, Cantatore G, Otero XL, Martin-Biedma B. Alternating versus Continuous Rotation: A Comparative Study of the Effect on Instrument Life. ] Endod. 2010;36(1):157-9.

11. You SY, Bae KS, Baek SH, Kum KY, Shon W], Lee W. Lifespan of one nickel-titanium rotary file with reciprocating motion in curved root canals. ] Endod. 2010;36(12):1991-4.

12. Schneider SW. A comparison of canal preparations in straight and curved root canals. Oral Surg Oral Med Oral Pathol. 1971:32(2):271-5.

13. Gambill JM, Alder M, del Rio CE. Comparison of nickel-titanium and stainless steel hand-file instrumentation using computed tomography. ] Endod. 1996;22(7):369-75.

14. Troian CH, Só MVR, Figueiredo JAP, Oliveira EPM. Deformation and fracture of RaCe and K3 endodontic instruments according to the number of uses. Int Endod ]. 2006;39(8):616-25.

15. Siqueira JF. Endodontic infections: Concepts, paradigms, and perspectives. Oral Surg Oral Med Oral Pathol Oral Radiol Endod. 2002;94(3):281-93.

16. Signoretti FCC, Endo MS, Gomes BPFA, Montagner F, Tosello FB, Jacinto RC. Persistent extraradicular infection in root-filled asymptomatic human tooth: Scanning electron microscopic analysis and microbial investigation after apical microsurgery. J Endod. 2011;37(12):1696-700.

17. Tziafas D, Alraeesi D, Hormoodi R Al, Ataya M, Fezai H, Aga N. Preparation prerequisites for effective irrigation of apical root canal: A critical review. J Clin Exp Dent. 2017;9(10):e1256-63.

18. Borlina SC, De Souza V, Holland R, Murata SS, Comes-Filho JE, Dezan Junior E, et al. Influence of apical foramen widening and sealer on the healing of chronic periapical lesions induced in dogs' teeth. Oral Surgery, Oral Med Oral Pathol Oral Radiol Endodontology. 2010;109(6):932-40. 
19. Elayouti A, Dima E, Judenhofer MS, Löst C, Pichler B]. Increased apical enlargement contributes to excessive dentin removal in curved root canals: A stepwise microcomputed tomography study. ] Endod. 2011;37(11):1580-4.

20. Estrela C, Holland R, Estrela C R A, Alencar A H G, Sousa-Neto M D PJD. Characterisation of Successful Root Canal Treatment. Braz Dent ]. 2014;25(1):3-11.

21. Haapasalo M, Endal U, Zandi H, Coil JM. Eradication of endodontic infection by instrumentation and irrigation solutions. Endod Top. 2005;10(1):77-102.

22. Widmer C, Skutas ], Easson C, Lopez ] V., Torneck C, Flax M, et al. Culture-independent Characterization of the Microbiome of Healthy Pulp. J Endod. 2018;44(7):1132-1139.e2.

23. Pasqualini D, Alovisi M, Cemenasco A, Mancini L, Paolino DS, Bianchi CC, et al. Micro-Computed Tomography Evaluation of ProTaper Next and BioRace Shaping Outcomes in Maxillary First Molar Curved Canals. ] Endod. 2015;41(10):1706-10.

24. Gagliardi ], Versiani MA, De Sousa-Neto MD, Plazas-Garzon A, Basrani B. Evaluation of the shaping characteristics of ProTaper Gold, ProTaper NEXT, and ProTaper Universal in curved canals. J Endod. 2015;41(10):1718-24.

25. Elnaghy AM, Al-Dharrab AA, Abbas HM, Elsaka SE. Evaluation of root canal transportation, centering ratio, and remaining dentin thickness of TRUShape and ProTaper Next systems in curved root canals using micro-computed tomography. Quintessence Int. 2017;48(1):27-32.

26. Paqué F, Zehnder M, De-Deus G. Microtomography-based comparison of reciprocating single-file F2 ProTaper technique versus rotary full sequence. ] Endod. 2011;37(10):1394-7.

27. Do Amaral ROJF, Leonardi DP, Gabardo MCL, Coelho BS, Oliveira KV De, Baratto Filho F. Influence of cervical and apical enlargement associated with the wave one system on the transportation and centralization of endodontic preparations. J Endod. 2016;42(4):626-31.

28. Jardine AP, Rosa RA, Santini MF, Zaccara IM, Só MVR, Kopper PMP. Shaping ability of rotatory or reciprocating instruments in curved canals: a micro-computed tomographic study. Braz Oral Res. 2016;30(1):1-8.

29. Arslan H, Khalilov R, Doğanay E, Karatas E. The effect of various kinematics on postoperative pain after instrumentation: a prospective, randomized clinical study. J Appl Oral Sci. 2016;24(5):503-8.

30. Navós B, Hoppe C, Mestieri L, Böttcher D, Só MR, Grecca F. Centering and transportation: in vitro evaluation of continuous and reciprocating systems in curved root canals. J Conserv Dent. 2016;19(5):478-81.

31. Giuliani V, Di Nasso L, Pace R, Pagavino G. Shaping ability of waveone primary reciprocating files and ProTaper system used in continuous and reciprocating motion. J Endod. 2014;40(9):1468-71.

32. De-deus G, Belladonna FG, Nogueira E], Lopes RT, Versiani MA, Paciornik S, et al. Micro-CT Evaluation of Non-instrumented Canal Areas with Different Enlargements Performed by NiTi Systems. Braz Dent ]. 2015;26(6):624-9.

33. Kim HC, Hwang Y], Jung DW, You SY, Kim HC, Lee W. Micro-computed tomography and scanning electron microscopy comparisons of two nickel-titanium rotary root canal instruments used with reciprocating motion. Scanning. 2013;35(2):112-8.

34. Arantes WB, Da Silva CM, Lage-Marques JL, Habitante S, Da Rosa LCL, De Medeiros JMF. SEM analysis of defects and wear on Ni-Ti rotary instruments. Scanning. 2014;36(4):411-8.

35. Murali Krishna Chakka N V., Ratnakar P, Das S, Bagchi A, Kumar S, Anumula L. Do NiTi instruments show defects before separation? Defects caused by torsional fatigue in hand and rotary nickel-titanium (NiTi) instruments which lead to failure during clinical use. ] Contemp Dent Pract. 2012;13(6):867-72.

36. Kaval ME, Capar ID, Ertas H, Sen BH. Comparative evaluation of cyclic fatigue resistance of four different nickel-titanium rotary files with different cross-sectional designs and alloy properties. Clin Oral Investig. 2017;21(5):1527-30.

37. Tokita D, Ebihara A, Miyara K, Okiji T. Dynamic Torsional and Cyclic Fracture Behavior of ProFile Rotary Instruments at Continuous or Reciprocating Rotation as Visualized with High-speed Digital Video Imaging. ] Endod. 2017;43(8):1337-42

38. Ferreira FC, Barbosa IB, Scelza P, Montagnana MB, Russano D, Neff], et al. Noncontact three-dimensional evaluation of surface alterations and wear in NiTi endodontic instruments. Braz Oral Res. 2017;31:1-9. 